\title{
Perancangan Komunikasi Visual Sebagai Media Edukasi Terhadap Pecandu Mobile Online Games
}

\author{
Lambang Hernanda \\ Program Pascasarjana Institut Seni Indonesia Yogyakarta \\ l.hernanda@gmail.com
}

\begin{abstract}
The rapid development of science and technology brings changes in all walks of life. Human creativity is growing so as to encourage the acquisition of new findings in the field of technology that is used as a means of improving the welfare of humanity. One product of human creativity is an online game. As a media, internet games are very influential on the human mind which is absorbed through the two senses, namely seeing and hearing.Online gaming is a new lifestyle for some people in every age group. In the perspective of sociology, people who make online games opium, tend to be egocentric and put forward individualism. This is dangerous for the social life of the individual, they naturally move away from the surrounding environment and it is possible to marginalize themselves so that they assume that their life is in cyberspace and their social environment is only where they play the game. From the problems above, we need a solution that is expected to reduce, manage the level of addiction to mobile online games for adolescent behavior. This design is expected to be able to contribute to the prevention and management of mobile online games addiction for teenagers so that the future of the nation's next generation is more qualified.
\end{abstract}

Keywords. Technology, Online Games, Addictions.

Relevance to Visual Communication Design Practice. Design Thinking is one of the new methods in the design process. Design Thinking is a method of solving problems that focus on the user.

\section{LATAR BELAKANG MASALAH}

Perkembangan ilmu pengetahuan dan teknologi yang semakin pesat membawa perubahan dalam segala lapisan kehidupan masyarakat. Kreatifitas manusia semakin berkembang sehingga mendorong munculnya temuan-temuan baru dalam bidang teknologi yang dimanfaatkan sebagai sarana peningkatan kesejahteraan umat manusia. Salah satu produk kreatifitas manusia tersebut adalah internet. Teknologi internet dewasa ini berkembang pesat, salah satunya sebagai sarana hiburan, misalnya untuk bermain.

Permainan dengan menggunakan koneksi internet ini disebut game online. Sebagai media, game online sangat berpengaruh terhadap pikiran manusia yang diserap melalui dua panca indera yakni melihat dan mendengar. Seiring dengan perkembangan dan kemajuan teknologi, game sangat berkembang pesat, antara lain semakin baiknya mutu dan kualitas game online yang ada sekarang ini menyebabkan peminat game online semakin banyak. Ditambah lagi dengan perangkat perangkat smartphone yang semakin canggih dan memiliki fitur yang mendukung untuk bermain game online.

Game online merupakan sebuah gaya hidup baru bagi beberapa orang disetiap kalangan umurnya. Dalam perspektif sosiologi orang yang menjadikan game online sebagai candu, cenderung akan 
menjadi egosentris dan mengedepankan individualis. Hal ini berbahaya bagi kehidupan sosial individu tersebut, mereka dengan sendirinya menjauh dari lingkungan sekitar dan dimungkinkan akan memarjinalkan diri sehingga beranggapan bahwa kehidupannya adalah di dunia maya dan lingkungan sosialnya hanya pada dimana tempat dia bermain game tersebut. Banyak diantara mereka dari golongan pelajar sekolah dasar sampai jenjang perguruan tinggi, baik dari status dan golongan ekonomi menengah kebawah sampai menengah keatas.

Perlu kita sadari bahwa perkembangan game online saat ini memiliki dampak negatif. Dampak negatif yang paling bisa dirasakan adalah kecanduan. Kecanduan dapat diartikan sebagai suatu kondisi dimana individu merasa ketergantungan terhadap suatu hal yang disenanginya pada berbagai kesempatan yang ada yang disebabkan karena kurangnya kontrol diri sehingga dapat menimbulkan perilaku yang kompulsif dan dapat menyebabkan dampak yang negatif.

Apabila seseorang telah menjadi pecandu maka akan berdampak pada keadaan psikis maupun fisiknya, khususnya seseorang yang kecanduan permainan internet. Situasi kehidupan yang seperti ini memiliki pengaruh yang sangat kuat terhadap dinamika kehidupan manusia terutama remaja. Saat ini remaja sedang berada pada masa mencari jati diri. Remaja adalah mereka yang sedang mengalami perubahan dari masa kanak-kanak ke masa dewasa. Perubahan tersebut mencakup perubahan fisik dan perubahan emosional yang kemudian tercemin dalam sikap dan tingkah laku. Perkembangan arus informasi media masa baik berupa majalah, surat kabar, tabloid, maupun media elektronik seperti radio, televisi, dan internet mempercepat terjadinya perubahan tersebut.

Pada masa sekarang ini remaja cenderung kurang suka untuk bekerja maupun belajar dan kadang menunjukkan sifat negatif dan agresif terhadap masyarakat. Remaja lebih cenderung menghabiskan waktunya dengan hal-hal yang disukainya dan melakukan aktifitas rekreasi yang sedang populer di kalangan sebayanya dan salah satu permainan yang sedang populer saat ini adalah game online. Game online ialah game yang dapat dimainkan oleh multi pemain melalui internet.

Hal yang mengkhawatirkan, dimana remaja yang pada umumnya masih duduk di bangku sekolah dan perguruan tinggi menghabiskan waktu dengan main game online sehingga menyebabkan merosotnya prestasi belajar mereka. Begitu juga remaja dapat tidak mempunyai kemampuan untuk bersosialisasi dengan baik dalam lingkungan keluarga maupun lingkungan pergaulannya di masyarakat.

Dari permasalahan di atas maka perlu sebuah solusi yang diharapkan bisa mengurangi, mengelola tingkat kecanduan atas mobile online games terhadap perilaku remaja. Perancangan ini nantinya diharapkan mampu memberikan kontribusi terhadap pencegahan dan pengelolaan atas kecanduan mobile online games untuk remaja sehingga masa depan generasi penerus bangsa lebih berkualitas. 


\section{Rumusan perancangan}

Bagaimana merancang komunikasi visual guna memberikan edukasi bagi remaja pecandu Mobile Online Games?

\section{Tujuan perancangan}

Tujuan dari perancangan ini adalah merancang desain komunikasi visual guna memberikan edukasi bagi remaja pecandu Mobile Online Games yang memiliki daya tarik secara visual.

\section{Manfaat perancangan}

\section{Teoretis}

- Perancangan komunikasi visual ini dapat menjadi referensi, sumber penggalian ide dan alternatif solusi permasalahan desain komunikasi visual bagi desainer komunikasi visual.

- Perancangan komunikasi visual ini dapat memberikan wawasan tentang kajian pengaruh kecanduan mobile online game terhadap perilaku remaja.

\section{Praktis}

- Industri kreatif

Perancangan komunikasi visual ini dapat mendukung perkembangan industri kreatif New Media.

- Civitas akademia DKV

Bagi mahasiswa DKV perancangan komunikasi visual ini dapat menjadi referensi bagaimana merancang komunikasi visual sebagai solusi pemecahan masalah DKV.

- Masyarakat

Perancangan komunikasi visual ini dapat memberikan edukasi bagi remaja pecandu Mobile Online Games.

\section{METODE PERANCANGAN}

Metode perancangan yang digunakan dalam perancangan ini mengacu pada metode Design Thinking oleh Tim Brown yang meliputi lima tahapan, yaitu: Empathize, Define, Ideate, Prototype, dan Test. Tahapantahapan perancangan ini dapat di uraiakan sebagai berikut:

Dalam perancangan ini perancang melakukan pengamatan pada user serta perilaku dalam kehidupan sehari - hari, berinteraksi, dan merasakan apa yang dialami oleh target perancangan.

Tahapan empati ini perlu dilakukan untuk menyaksikan apa yang dilakukan target dan bagaimana mereka berinteraksi dengan lingkungannya untuk mendapatkan petunjuk tentang apa yang mereka pikirkan dan rasakan. Hal ini juga membantu untuk mempelajari apa yang mereka butuhkan.

\section{LANDASAN TEORI}

\section{Design Thinking Tim Brown}

Perancangan ini mengacu pada kerangka Design Thinking oleh Tim Brown yang meliputi lima tahapan, yaitu : Empathize, Define, Ideate, Prototype, dan Test. Tahapan tahapan perancangan dapat digambarkan sebagai berikut:

\section{Empathize}

Dalam perancangan ini perancang melakukan pengamatan pada user serta perilaku dalam kehidupan sehari - hari, berinteraksi, dan merasakan apa yang dialami oleh target perancangan.

Tahapan empati ini perlu dilakukan untuk menyaksikan apa yang dilakukan target dan bagaimana mereka berinteraksi dengan lingkungannya untuk mendapatkan 
petunjuk tentang apa yang mereka pikirkan dan rasakan. Hal ini juga membantu untuk mempelajari apa yang mereka butuhkan.

\section{Define}

Pemahaman terhadap permasalahan yang dirumuskan dalam sebuah pernyataan permasalahan yang tepat untuk dieksekusi atau juga dinamakan POV (Point of View) juga mengekspresikan permasalahan yang akan diselesaikan.

\section{Ideation}

Setelah mendapatkan permasalahan inti, langkah selanjutnya adalah menghasilkan dan mengembangkan ide-ide yang mungkin sebagai solusi dari permasalahan yang dialami. Ide ini nantinya dapat menjadi prototipe inovasi dari seperangkat solusi.

\section{Prototype}

Mengubah ide - ide yang sudah dikumpulkan ke dalam bentuk fisik atau nyata. Secara tradisional yaitu sebagai jalan untuk melakukan tes fungsionalitasnya. Pembuatan prototipe digunakan untuk berbagai alasan, seperti: mendapatkan simpati, explorasi, testing, inspirasi, belajar, dan mengatur proses penciptaan solusi. Prototyping ini tidak melulu harus dalam bentuk fisik yang sempurna dan mahal. Bisa dimulai dengan menggunakan sketsa atau gambaran kasar hingga menjadi model yang lebih konkret. Dan yang terpenting prototyping ini harus bisa dicoba oleh calon pengguna akhir.

\section{Test}

Tahapan terakhir adalah dengan menguji hasil prototyping yang telah dibuat dan mengevaluasinya apakah masih ada masalah atau kekurangan yang dinilai sangat mengganggu. Memastikan produk tersebut sudah sesuai dengan solusi yang diharapkan dan bisa menjawab kebutuhan pengguna atau tidak. Tahapan ini dilakukan untuk mempelajari target lebih dalam, mendapatkan solusi, menguji atau mengetes dan memperbaiki POV.

\section{PEMBAHASAN}

\section{Empathize}

Dalam tahap perancangan ini proses empathize mendapatkan berbagai data terkait dengan perancangan komunikasi visual guna mengedukasi remaja pecandu mobile online games. Data yang didapat adalah sebagai berikut:

\section{Identifikasi Permasalahan}

Identifikasi permasalahan diawali dengan pengumpulan data terkait masalah kecanduan Mobile Online Games melalui observasi lapangan, buku, jurnal dan artikel online.

\section{Target audiens perancangan}

Target audiens primer diidentifikasikan sebagai remaja (akhir) menuju dewasa (awal) dalam rentang usia produktif dengan tingkat perekonomian menengah menengah dan menengah keatas. Karakteristik target audiens dalam perancangan ini adalah sebagai berikut:

- Demografis:

Remaja dan dewasa dalam rentang usia produktif dengan perkiraan usia 19 - 30 tahun. Tingkat perekonomian menengahmenengah dan menengah keatas. Tingkat pendidikan perguruan tinggi. 
- Geografis:

Tinggal di wilayah Yogyakarta

- Psikografis:

Memiliki ketertarikan terhadap Mobile Online Games.

- Behaviour:

Remaja dan dewasa yang masih duduk di bangku sekolah dan kuliah, up-date dan mengikuti tren, memiliki sosial media, pengguna aktif internet, pemain mobile online games.

Sedangkan target audiens sekunder dalam perancangan ini adalah seluruh masyarakat Indonesia yang memiliki sosial media dan sebagai pengguna aktif sosial media.

\section{Data Lapangan}

Kini game online bukan hanya menjadi sebuah hiburan yang banyak dinikmati oleh semua orang dari berbagai kalangan. Namun sesuai dengan perkembangannya, bermain game kini pun sudah menjadi semacam hobi yang dilakukan oleh orang muda sampai dengan tua dengan berbagai latar belakang yang berbeda.

Mobile online games jika sudah pahami berinternet, maka sangat mudah untuk dimainkan, operasikan, tergantung keterampilan tangan, kecepatan daya pikir, dan reaksi terhadap bentuk serta gerakan yang ada pada layar game. Mobile online games pun mampu dimainkan oleh semua kalangan, dan hampir tak ada batas usia, latar pendidikan, jabatan, dan fungsi sosial.

Keterikatan pada waktu penyelesaian tugas di game dan rasa asik memainkannya seringkali membuat berbagai kegiatan terbengkalai. Waktu beribadah, tugas sekolah, tugas kuliah ataupun perkerjaan menjadi terbengkalai karena bermain game atau memikirkannya. Apalagi banyak permainan yang terus berjalan meskipun kita sudah offline.

Jika menang, maka akan ada soraksorai gembira, bahkan teriakan hore dan binggo, dan lain sebagainya. Namun jika mereka kalah, maka biasanya, karena emosi kekalahan, sering keluar kata-kata sumpah serapah, cacian, kata-kata kotor, bahkan memaki kepada lawan (yang ada di seberang lain). Selama bermain pun, biasanya diwarnai dengan suasana bising, gembira, ramai, dan lain sebagainya. Pada situasi dan kondisi seperti itu, untuk mereka yang telah kecanduan, yang menjadikan lupa banyak hal, termasuk belajar, makan, minum dan lain sebagainya.

Dari melakukan empati, perancang mencoba mendalami tentang game online smartphone. Pada akhirnya perancang masuk sebuah grup gamers. Grup WA ini berisi mahasiswa dari berbagai perguruan tinggi bahkan ada yang masih duduk di bangku SMA. 


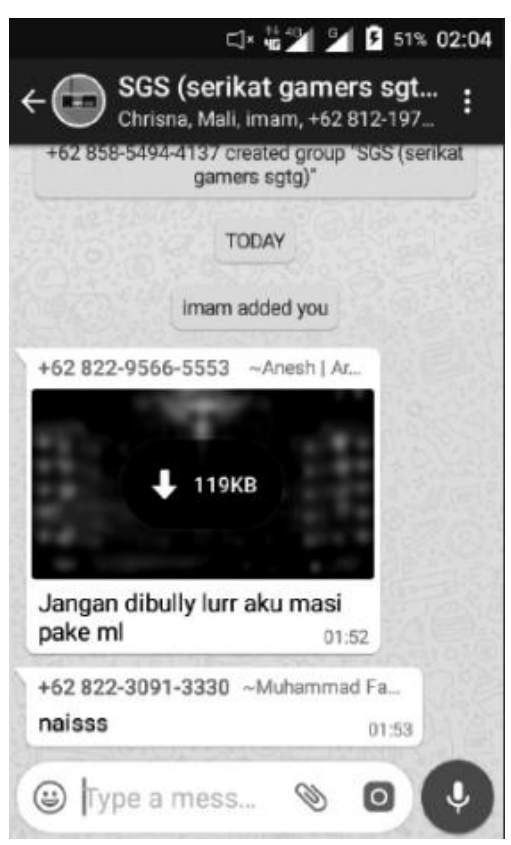

Gambar 1 Grup WA gamer Sumber : Dokumentasi Perancang

\section{Data Visual}

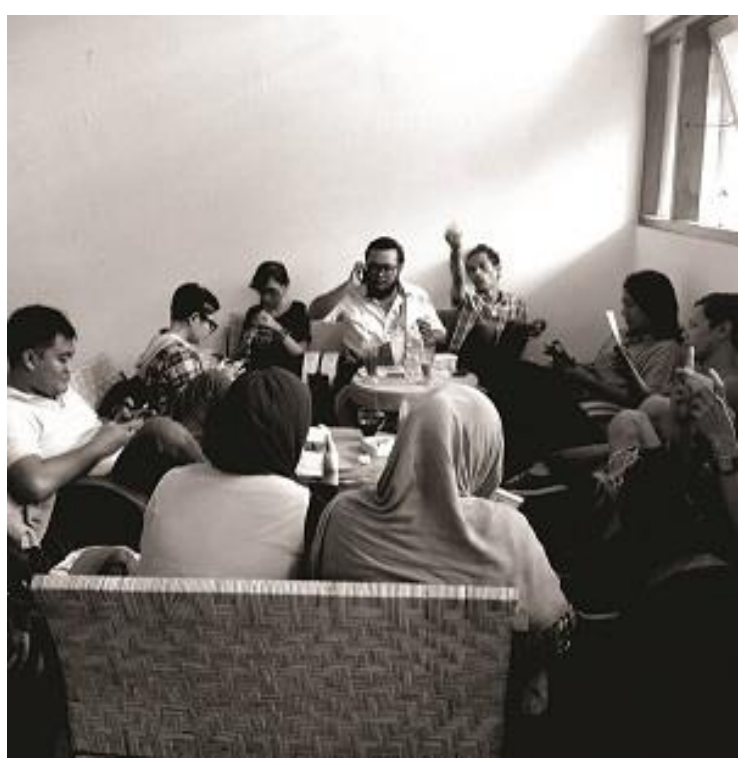

Gambar 2 Mahasiswa bermain game smartphone Sumber: Dokumentasi Perancang

\section{Define}

Pemahaman terhadap objek permasalahn dirumuskan dalam sebuah pernyataan permasalahan yang tepat untuk dieksekusi atau juga dinamakan POV ( Point of View) juga mengekspresikan permasalahan yang akan diselesaikan.

Konteks perancangan dianalisis dengan metode $5 W+1 H$ (What, Who, Where, When, Why dan How). Hasil dari analisis adalah sebagai berikut:

\section{- What}

Apa yang akan disampaikan dalam komunikasi visual ini?

Dalam perancangan ini akan disampaikan tentang perbandingan perilaku remaja saat belajar dan bermain Mobile Online Game.

- Who

Kepada siapa komunikasi visual ini ditujukan?

Target primer dari perancangan ini adalah remaja dan dewasa yang masih duduk di bangku sekolah dan kuliah, update dan mengikuti tren, memiliki sosial media, pengguna aktif internet, pemain mobile online games.

Sedangkan target audiens sekunder dalam perancangan ini adalah seluruh masyarakat Indonesia yang memiliki sosial media dan sebagai pengguna aktif sosial media.

- Where

Dimana perancangan ini akan di komunikasikan?

$$
\text { Perancangan ini akan }
$$
dikomunikasikan di wilayah Indonesia.

- When

Kapan perancangan ini akan dipublikasikan?

Perancangan ini akan di publikasikan setelah melakukan test atau uji coba ke target secara langsung.

- Why

Kenapa perancangan ini menjadi penting? 
Perkembangan game online saat ini memiliki dampak negatif. Dampak negatif yang paling bisa dirasakan adalah kecanduan. Kecanduan dapat diartikan sebagai suatu kondisi dimana individu merasa ketergantungan terhadap suatu hal yang disenanginya pada berbagai kesempatan yang ada yang disebabkan karena kurangnya kontrol diri sehingga dapat menimbulkan perilaku yang kompulsif dan dapat menyebabkan dampak yang negatif.

Hal yang mengkhawatirkan, dimana remaja yang pada umumnya masih duduk di bangku sekolah dan perguruan tinggi menghabiskan waktu dengan main game online sehingga menyebabkan merosotnya prestasi belajar mereka. Begitu juga remaja dapat tidak mempunyai kemampuan untuk bersosialisasi dengan baik dalam lingkungan keluarga maupun lingkungan pergaulannya di masyarakat.

- How

Bagaimana hasil perancangan ini akan dipublikasikan?

Pesan-pesan dalam perancangan ini akan disajikan dalam serangkaian media yang disusun dalam sebuah program media. Media yang digunakan merupakan cakupan dari New Media yang bisa menjangkau target secara luas.

\section{Ideate}

\section{Konten Perancangan}

Setelah didapatkan permasalahan inti, langkah selanjutnya adalah menghasilkan dan mengembangkan ide-ide yang mungkin sebagai solusi dari permasalahan yang dialami. Ide ini nantinya dapat menjadi prototipe inovasi dari seperangkat solusi.
Dalam perancangan ini komunikasi visual dititik beratkan pada penggunaan ilustrasi perbandingan perilaku remaja dan dewasa saat bermain mobile online game dan saat belajar.

\section{What to say?}

Pesan yang akan disampaikan melalui perancangan ini adalah bagaimana perbandingan perilaku remaja saat bermain game dan saat belajar yang diharapkan dapat memberi edukasi bagi remaja pecandu mobile online games.

\section{How to say?}

Bentuk pesan visual yang disampaikan adalah ilustrasi. Ilustrasi yang menggambarkan perbandingan perilaku saat bermain mobile online game dan aktifitas belajar dikomunikasikan melalui New Media. New Media sangat mudah dan sangat cepat, dapat di akses di mana pun serta mendapatkannya sangat lah murah.

\section{Pesan Verbal}

Dasar tema perancangan ini adalah mengedukasi remaja pecandu mobile online game. Dari dasar tema dikembangkan menjadi sebuah copywriting yang menjadi judul kampanye dalam perancangan. Judul kampanye dari perancangan ini adalah :

"Life is a game" yang berarti hidup adalah permainan. Judul ini muncul dari sebuah sistem permainan yang di dalamnya ada menang dan kalah. Tapi dalam konteks perancangan ini menang dan kalah dalam kehidupan nyata. Dalam kenyataannya manusia hidup dalam persaingan untuk 
mendapatkan kemenangan. Sebagai generasi muda sudah sewajarnya memikirkan masa depan (dalam hal ini pendidikan) menjadi pemenang atau kalah.

\section{Pesan Visual}

\section{Ilustrasi}

Secara etimologi, Ilustrasi berasal dari bahasa Latin " Illustrate " yang berarti menjelaskan atau menerangkan. Jadi, Ilustrasi digunakan untuk memperjelas pesan atau informasi yang disampaikan. Menurut Soedarso (204: 566) salah satu jenis ilustrasi adalah karikatur dan khayalan. Karikatur adalah sebuah bentuk kritikan atau sindiran yang dalam penggambarannya telah terdapat penyimpangan proporsi. Dalam perancangan ini, perancang memilih jenis ilustrasi karikatur. Ilustrasi dalam perancangan ini merupakan elemen penting sebagai daya tarik.

\section{Warna}

Warna yang digunakan dalam perancangan ini adalah sebagai berikut:

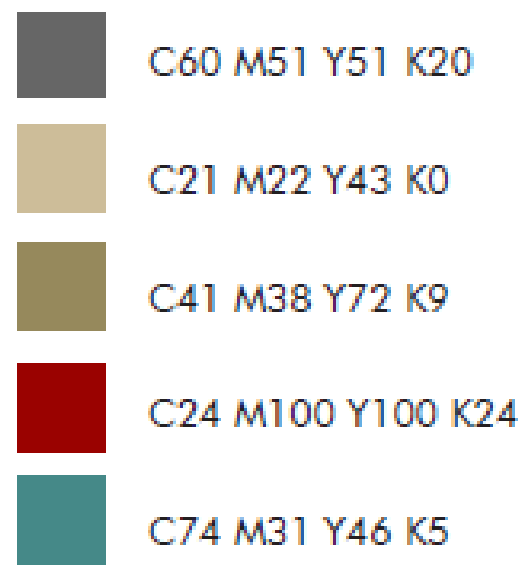

Gambar 3 Komparasi warna Sumber : Dokumentasi Perancang

\section{Tipografi}

Tipografi yang digunakan dalam perancangan ini mengutamakan aspek readibility dan legibility yaitu aspek kemudahan target audiens untuk mengenali masing - masing huruf dan memenuhi aspek keterbacaan. Sehingga dipilih jenis huruf sans serif. Berikut adalah jenis huruf yang dipilih dalam perancangan:

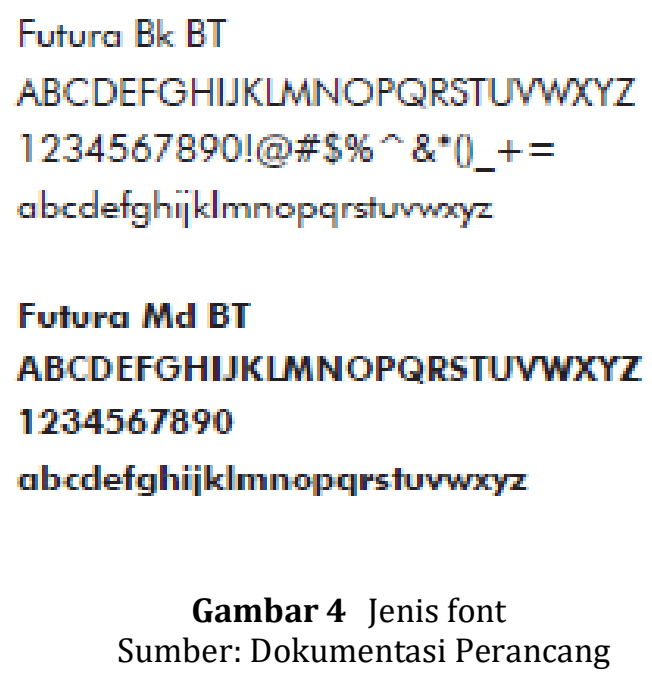

\section{Media Perancangan}

Permasalahan+Target Audiens = Media Media merupakan alat yang digunakan untuk menjangkau target audiens, dalam misi membawa pesan - pesan visual guna mengedukasi remaja pecandu Mobile Online Games. Media yang di pilih dalam perancangan ini merupakan bauran dari New Media. Penentuan media didasarkan pada hasil analisis Consumer Journey yang di lakukan terhadap target audiens.

Analisis consumer journey dilakukan untuk mengetahui aktifitas keseharian target audiens dari mulai bangun tidur sampai tidur lagi untuk mencari point of contact. Point of contact meliputi kegiatan, tempat, dan waktu. 
Sebelum melakukan analisis consumer journey, perlu dilakukan penentuan umur target audiens dengan rentang umur 19-30 tahun. Berikut adalah hasilnya:

19 tahun +30 tahun $=49$ tahun 49 tahun : $2=24,5$ tahun.

Dari analisis diatas dapat ditentukan target audiens yang akan di jadikan analisis consumer journey yaitu rentang umur 23 25 tahun.

Consumer Journey telah dilakukan kepada:

- Nama: Wahyu Aji Wicaksono

- Umur: 23

- Alamat: Sewon Indah

- Pekerjaan: Mahasiswa

Media-media yang menjadi point of contact berdasarkan analisis consumer journey terhadap target audiens perancangan adalah sebagai berikut:

- Sosial media yang diakses melalui smartphone

- Instagram

- Kamar tidur, kampus, kantin

Setelah ditemukan media - media dari point fo contact, kemudian media - media itu dibedakan berdasarkan media yang paling dekat dengan kehidupan target audiens, media yang bisa menjalin sinergi (saling memperkuat) dengan media lain serta realistis (sesuai kemampuan waktu, tenaga, dan dana). Media yang dipilih untuk mewujudkan dalam perancangan ini adalah melalui:

- Instagram ( New Media )

- Mural ( Ambient Media )

- Merchandise T-Shirt ( Media Konvensional)

\section{Prototype}

Mengubah ide - ide yang sudah dikumpulkan ke dalam bentuk fisik atau nyata. Secara tradisional yaitu sebagai jalan untuk melakukan tes fungsionalitasnya. Pembuatan prototipe digunakan untuk berbagai alasan, seperti : mendapatkan simpati, explorasi, testing, inspirasi, belajar, dan mengatur proses penciptaan solusi. Prototyping ini tidak melulu harus dalam bentuk fisik yang sempurna dan mahal. Bisa dimulai dengan menggunakan sketsa atau gambaran kasar hingga menjadi model yang lebih konkret. Dan yang terpenting prototyping ini harus bisa dicoba oleh calon pengguna akhir.

\section{Master Desain}

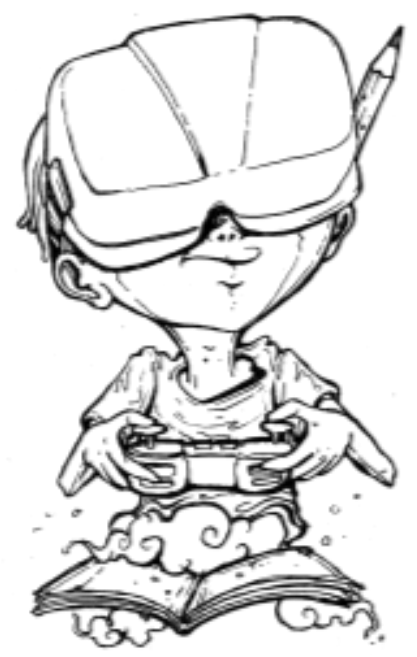

Gambar 5 Master desain 1 Sumber : Dokumentasi Perancang

Ilustrasi ini menggambarkan aktifitas remaja yang sedang asyik bermain game online dengan smartphonenya dengan menggunakan Virtual Reality. Ini menggambarkan sebuah fenomena yang sedang terjadi saat ini. Kehidupan remaja 
yang hidup di masa milenial. Mereka lebih suka bermain game daripada belajar.

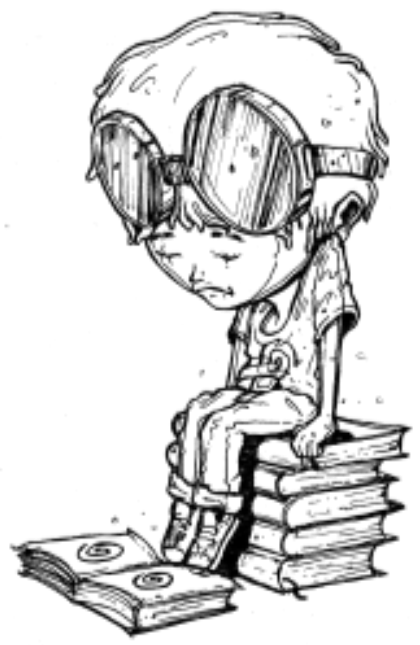

Gambar 6 Master desain 2 Sumber : Dokumentasi Perancang

Ilustrasi ini menggambarkan kehidupan remaja yang hidup di masa milenial lebih senang dan semangat bermain game di smartphone-nya daripada membaca buku pelajaran yang memberikan pengetahuan untuk mendukung pendidikannya. Secara simbolis digambarkan melalui ekspresi wajah yang dan ilustrasi remaja yang menggunakan tumpukan buku untuk duduk. Ditambah dengan satu buku yang terbuka dengan objek spiral yang seolah-olah buku ini mebuat remaja ini pusing dan akibatnya malas untuk belajar.

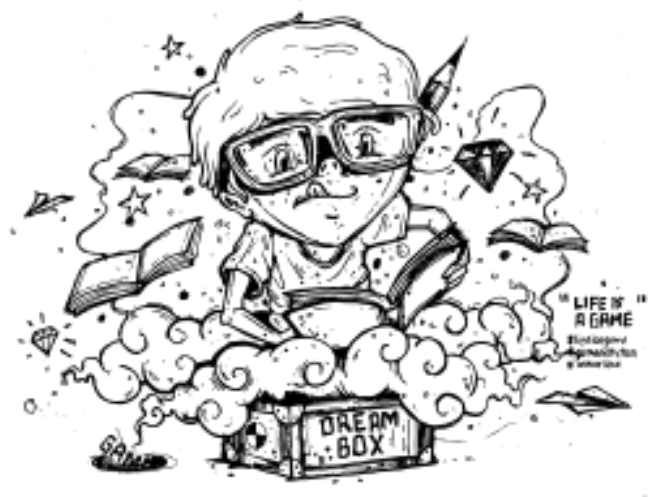

Gambar 7 Master desain 3

Sumber : Lambang Hernanda

Di dalam desain mural ini terdapat figur remaja yang sedang memegang sebuah buku yang merepresentasikan remaja tersebut sedang belajar. Terdapat sebuah kotak bertuliskan Dream Box yang mempunyai maksud bahwa sebagai remaja generasi penerus bangsa seharusnya lebih mengutamakan belajar daripada bermain game online. Background merah menggambarkan sebuah semangat remaja tersebut dalam meraih mimpi melalui belajar.

Pada bagian pojok kanan bawah terdapat tulisan Life is a Game dan hashtag. Teks tersebut memberi petuk dan bertujuan untuk mengarahkan target audiens ke akun instagram yang dicantumkan di bawah hashtag, dengan menggunakan pendekatan pemberian hadiah spesial.

\section{Test}



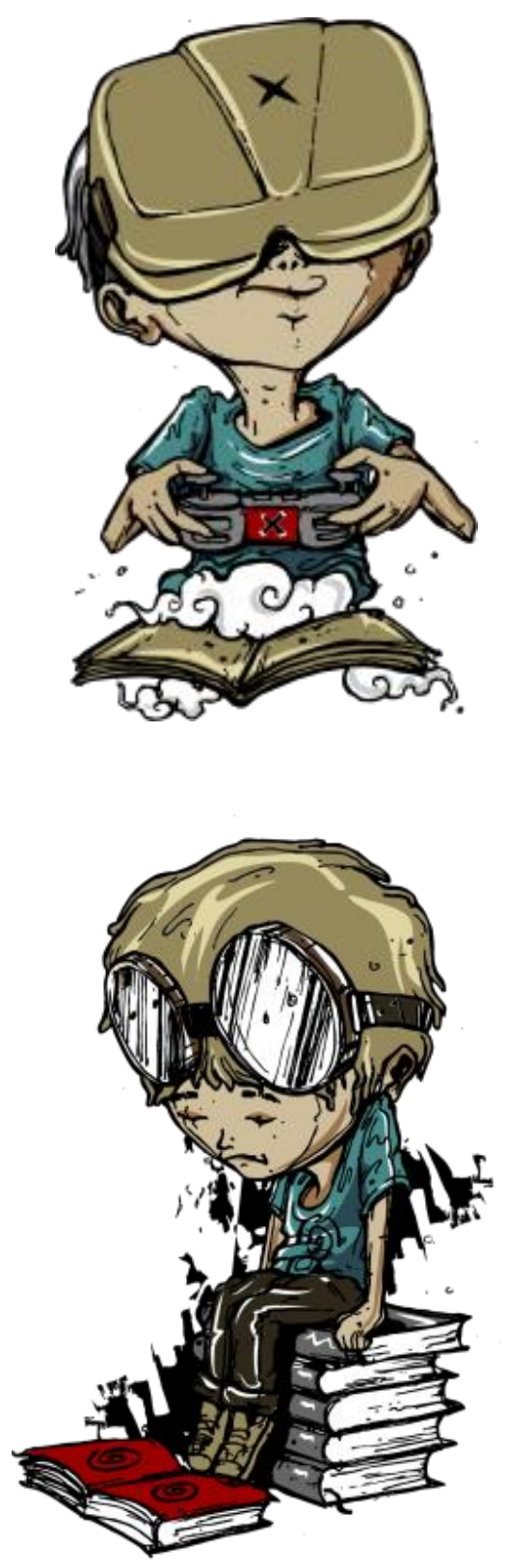

\section{Sosial Media}
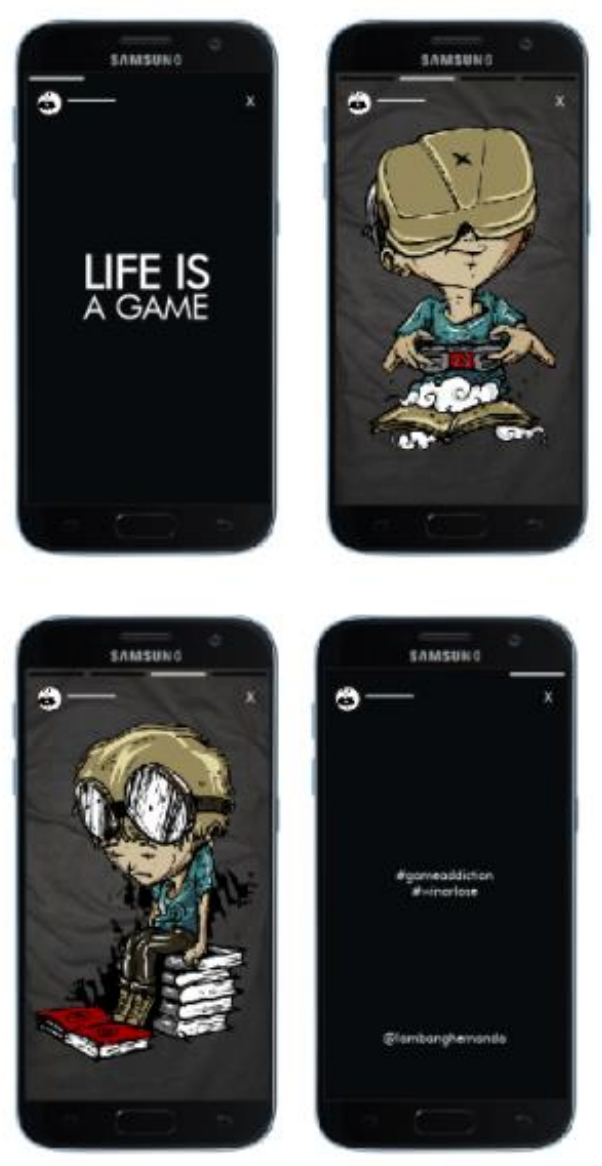

Gambar 8 Story Instagram

Sumber: Dokumentasi Perancang

Banyaknya pengguna instagram menjadi salah satu peluang bagi perancang untuk memanfaatkan fitur Insta Stories sebagai media untuk melakukan kampanye. Selain untuk menghemat biaya disisi lain instagram memiliki keunggulan lainnya yaitu jangkauan yang luas. Dengan instastory ini diharapkan pesan dan tujuan dari perancangan ini dapat tersampaikan pada target audiens.

Instastory dalam perancangan ini dibagi menjadi 4 bagian. Bagian pertama menampilkan judul dari kampanye. Sengaja memang untuk tidak menjelaskan apa maksud dari judul tersebut. 
Bagian kedua dan ketiga hanya menampilkan visual ilustrasi dan bagian terakhir ditampilkan kata kunci dengan menggunakan hashtag dan dilengkapi dengan link akun instagram dari perancang. Target audiens akan diarahkan masuk ke akun perancang dan melihat apa yang di upload oleh perancang berkaitan dengan instastory ini. Caption yang ditulis pada feed instagram adalah sebuah pertanyaan yang menanyakan apa maksud dari ilustrasi yang di upload. Jika target audiens mampu menjawab akan mendapatkan hadial spesial. Hadiahnya berupa T-Shirt dari ilustrasinya.

\section{Ambient media mural}

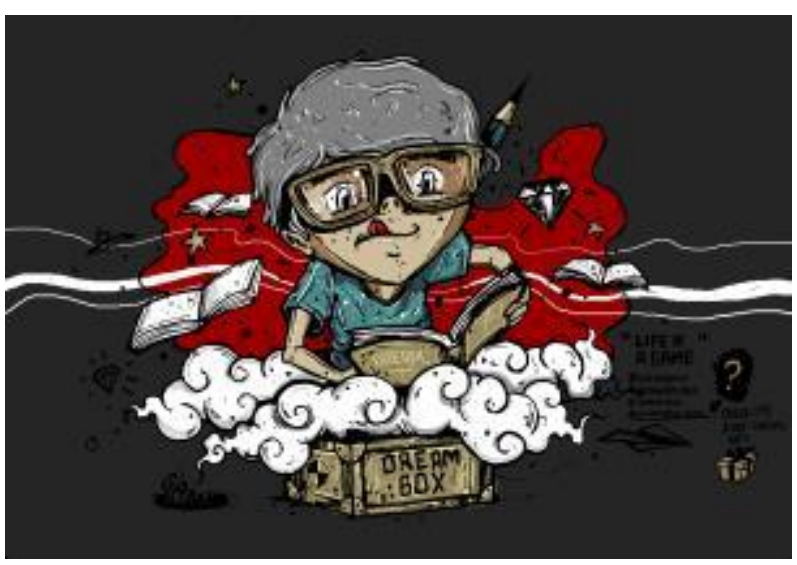

Gambar 9 Desain Mural Sumber : Dokumentasi Perancang
Ambient media merupakan salah satu strategi beriklan yang tujuan utamanya adalah untuk membangkitkan feeling dan mood konsumen agar merasa nyaman dan suka ketika berinteraksi dengan produk atau layanan yang ditawarkan oleh produsen.

Semangat yang dibawa oleh ambient media adalah memberikan memorable experience kepada konsumen. Dalam perkembangannya ambient media menjadi sebuah kegiatan below the line yang terintegrasi dengan media. Ambient media juga bisa disebut sebagai media lingkungan (Lwin dan Aitchison 2002). Ambient media dalam perancangan ini menggunakan media mural.

Mural menurut Susanto (2002: 76). memberikan definisi sebagai lukisan besar yang dibuat untuk mendukung ruang arsitektur.

Menurut Barry (2008: 67) sebuah lukisan pada dinding, langit-langit ruang, atau tempat permanen dengan ukuran yang besar seperti dinding, trotoar dan media yang berada di ruang publik. Mural akan diaplikasikan pada media dinding yang berada dekat atau di lokasi game centre di wilayah Yogyakarta. 


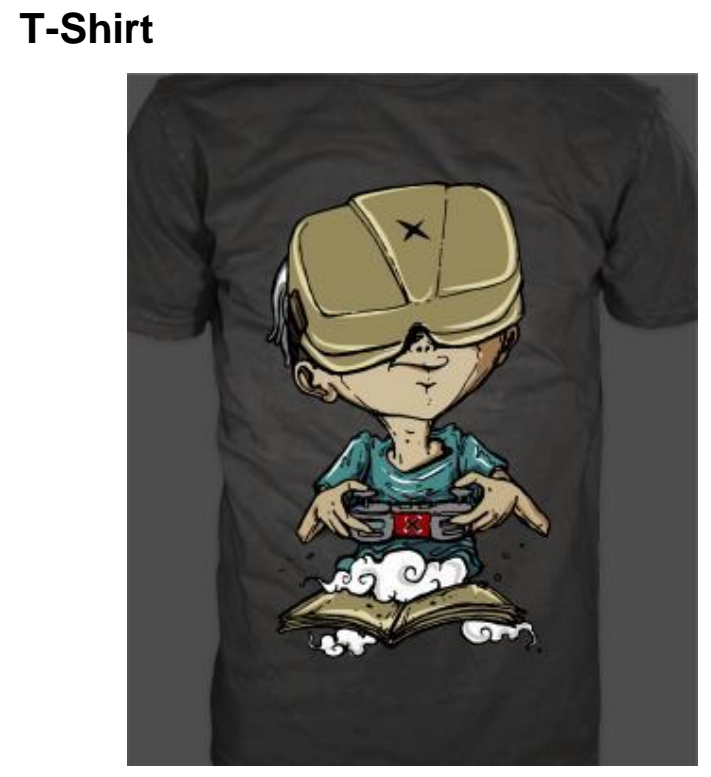

Gambar 10Pengaplikasian pada T-Shirt 1 Sumber : Dokumentasi Perancang

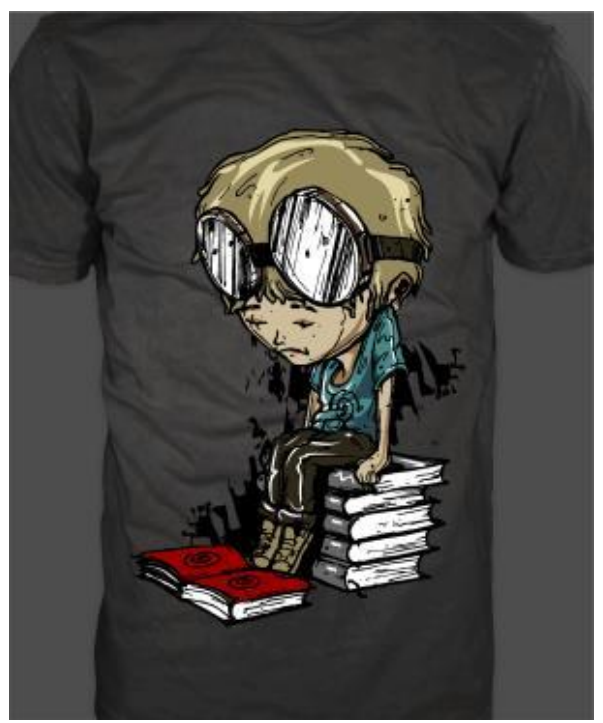

Gambar 11Pengaplikasian pada T-Shirt 2 Sumber : Dokumentasi Perancang

\section{KESIMPULAN}

Perancangan komunikasi visual ini bertujuan untuk memberi edukasi remaja pecandu mobile online game tentang dampak negatif dari kecanduan mobile online game terhadap perilaku remaja yang memiliki daya tarik secara visual.
Berdasarkan pengamatan secara langsung, di era milenial ini remaja cenderung lebih suka bermain game online daripada belajar. Hal ini memberikan dampak negatif terhadap perilaku remaja itu sendiri.

Sebagai upaya pemecahan masalah tersebut, maka dirancang sebuah solusi dalam bentuk kampanye yang berjudul "Life is a Game". Kampanye ini menekankan pada upaya edukasi terhadap remaja pecandu mobile online game melalui media - media yang telah diperoleh dari hasil wawancara tentang aktifitas keseharian target audiens dari mulai bangun tidur sampai tidur lagi untuk mencari point of contact. Point of contact meliputi kegiatan, tempat, dan waktu ini dijadikan acuan untuk penentuan media perancangan.

Media dalam perancangan ini dapat dijadikan alternatif solusi dalam membantu pemecahan permsalahan desain. Alternatif media yang dimaksud disini adalah media baru instagram.

Dengan merancang komunikasi visual guna memberi edukasi remaja pecandu mobile online game ini, perancang mendapatkan pelajaran tentang bagaimana menentukan visual dan media yang tepat agar pesan informasi bisa tersampaikan kepada target audiens dengan menggunakan analisis consumer journey.

\section{DAFTAR PUSTAKA}

Azis, 2011 Hubungan Kecanduan Game Online Dengan Self Esteem Remaja Gamers Di Kecamatan Lowokwaru Kota Malang. Skripsi Fakultas Psikologi Universitas Islam Negeri Maulana Malik Ibrahim Malang

Brown, Tim. 2009. Change by Design. New York : Harper Collins 
Lwin, M dan Jim Aitchison. 2002. Clueless in Advertising. New Jersey:Prentice Hall

Sihombing, D. 2001. Tipografi dalam Desain Grafis. Jakarta: Gramedia.

Susanto, Mikke. (2002),. Diksi Rupa. Yogyakarta: Kanisius.

Young, Kimberly S. 2017. Kecanduan Internet Panduan Konseling dan Petunjuk untuk Evaluasi dan Penanganan. Yogyakarta : Pustaka Pelajar.

\section{Website}

http://www.artikelsiana.com/2017/09/pe ngertian-ilustrasi-fungsi-tujuan.html dikases pada tanggal 4 Juni 2018.

Dewanto, 2007. Dampak Positif Dan Negative Game Online . diakses dari http://

library.gunadarma.ac.id/repository/file s/253952/10507235/bab-i.pdf pada tanggal tanggal 24 Maret 2018

https://cakshon.com/tag/menang-dankalah-dalam-kehidupan/ diakses pada tanggal 4 Juni 2018

http://blog.qontak.com/2017/06/17/3fungsi-beriklan-di-insta-sto ries-dancara-mengoptimalkannya/ diakses pada tanggal 4 Juni 2018

[1] http://blog.unnes.ac.id/rahinadkv/201 6/03/10/ambient-media/ diakses pada tanggal 6 Juni 2018 